\title{
EFEKTIFITAS TERAPI DEKAPAN IBU TERHADAP PENURUNAN INTENSITAS NYERI PADA BAYI YANG MENJALANI IMUNISASI
}

\author{
Fiki Wijayanti ${ }^{1}$, Natalia Devi Oktarina ${ }^{2}$ \\ ${ }^{1,2}$ Universitas Ngudi Waluyo Fakultas Kesehatan S1 Keperawatan \\ vie.qway@gmail.comnathadev86.nd@gmail.com \\ Jln. Diponegoro No. 186 Ungaran Timur Kab. Semarang- 50512
}

\begin{abstract}
ABSTRAK
Imunisasi merupakan salah satu cara memberikan kekebalan tubuh pada anak untuk mencegah penyakit. Pemberian imunisasi melalui suntikan dapat menimbulkan efek secara langsung yaitu rasa nyeri pada anak. Nyeri yang disebabkan oleh suntikan imunisasi jika tidak dikelola akan mengakibatkan dampak negatif pada aspek emosional pada anak seperti menangis dan ketakutan. Salah satu intervensi yang dapat dikembangkan dalam menerapkan perawatan atraumatik saat pemberian imunisasi pada anak adalah terapi dekapan ibu. Tujuan dalam penelitian ini adalah untuk menganalisis efektifitas terapi dekapan ibu terhadap nyeri pada bayi yang dilakukan imunisasi di Puskesmas Lerep. Jenis penelitian yang digunakan dalam penelitian ini adalah Preeksperimen design dengan rancangan pretest-post test control group design. Metode Pengambilan sampling menggunakan Purposive sampling dengan jumlah sampel pada kelompok kontrol sejumlah 30 bayi dan kelompok intervensi 30 bayi. Dalam penelitian ini ada 2 variabel yang diukur yaitu variabel Nyeri dan pemberian terapi dekapan ibu. Variabel nyeri diukur menggunakan instrument FLACC Pain Assessment Tools. Sedangkan variabel terapi dekapan ibu diukur dengan melakukan observasi saat pemberian imunisai. Uji statistik yang digunakan adalah dengan $t$ test-independent. Hasil yang didapatkan adalah $\mathrm{p}$ value 0,0001 . Berdasarkan hasil analisis diketahui bahwa ada perbedaan selisih rata-rata nyeri pada kelompok intervensi dan kontrol $(\mathrm{p}<0,05)$. Diharapakan Tenaga Kesehatan di Puskesmas menerapkan tindakan atraumatic care pada bayi yang akan dilakukan imunisasi dengan cara mengikutsertakan ibu dalam kegiatan imunisasi yaitu dengan dekapan ibu.
\end{abstract}

Kata Kunci : Nyeri, Bayi, imunisasi dan dekapan ibu

\section{ABSTRACT}

Immunization is a way to provide immunity to children to prevent disease. Immunization by injection can have a direct effect, namely pain in children. Pain caused by immunization injections if not managed will have a negative impact on emotional aspects in children such as crying and fear. One of the interventions that can be developed in implementing atraumatic care when immunizing children is mother's holding therapy. The purpose of this study was to analyze the effectiveness of holding therapy for pain in infants who were immunized at Lerep Public Health Center. The type of research used in this research is pre-experimental design with pretest-post test control group design. The sampling method used purposive sampling with the number of samples in the control group of 30 babies and the intervention group of 30 babies. In this study, there were 2 variables measured, namely the variable pain and offering mother's hug therapy. Pain variables were measured using the FLACC Pain Assessment Tools instrument. Meanwhile, the variable of mother's holding therapy was measured by observing when presenting immunizations. The statistical test used is the independent $t$ test. The result obtained is a p value of 0.0001. Based on the results of the analysis, it is known that there is a difference in the difference in mean pain between the intervention and control groups ( $p$ $<0.05)$. It is hoped that the health workers at the Public Health center will implement atraumatic care for babies who will be immunized by involving the mother in immunization activities, namely by holding the mother.

Keywords: pain, baby, immunization and holding therapy 


\section{LATAR BELAKANG}

Imunisasi merupakan salah satu cara memberikan kekebalan tubuh pada anak untuk mencegah penyakit. Pemberian kekebalan tubuh yang harus diberikan secara terus menerus, dan dilaksanakan sesuai standar mampu memberikan perlindungan kesehatan dan memutus mata rantai penularan (Potts\& Mandleco, 2012). Imunisasi adalah suatu cara untuk meningkatkan kekebalan seseorang secara aktif terhadap suatu penyakit, sehingga bila kelak terpapar dengan penyakit tersebut tidak akan menderita penyakit tersebut karena sistem imun tubuh mempunyai sistem memori (daya ingat), ketika vaksin masuk kedalam tubuh maka akan dibentuk antibody untuk melawan vaksin tersebut dan sistem memori akan menyimpannya sebagai suatu pengalaman (Ball, Bindler, \& Cowen, 2012).

Peran seorang ibu pada program imunisasi sangatlah penting. Pemberian imunisasi melalui suntikan dapat menimbulkan efek secara langsung yaitu rasa nyeri pada anak. Nyeri yang disebabkan oleh suntikan imunisasi jika tidak dikelola akan mengakibatkan dampak negatif pada aspek emosional pada anak seperti menangis dan ketakutan. Tangisan bayi adalah caranya berkomunikasi dan mengutarakan rasa sakit. Akan sulit untuk menginterpretasikan tangis bayi, khususnya untuk orang tua yang baru pertama kali menangani bayi dalam pemberian tindakan imunisasi. Hasil pengamatan yang menunjukkan bahwa setiap ibu yang hendak membawa anaknya untuk melakukan imunisasi, belum mengerti tentang cara-cara mengatasi nyeri akibat imunisasi (Sarimin, Monika, \& Jansen, 2015).

Secara umum nyeri adalah suatu rasa yang tidak nyaman, baik ringan maupun berat. Nyeri didefinisikan sebagai suatu keadaan yang mempengaruhi seseorang dan eksistensinya diketahui bila seseorang pernah mengalaminya (Mc Murtry, C. M et al, 2011). Menurut Craig et al, tahun 1984 (dalam Wong et al., 2009) bahwa bayi belum dapat mengungkapkan nyeri secara verbal, oleh karena itu pemahaman tentang perkembangan respon nyeri bayi sangatlah penting. Bayi muda dalam berepon terhadap nyeri dapat berupa memukul- mukul, menariknarik diri dari daerah yang terstimulasi, manangis keras, ekspresi nyeri terlihat pada wajah dengan alis menurun, dan berkerut secara bersamaan, mata tertutup, mulut terbuka lebar membentuk bujur sangkar. Bayi yang lebih besar Bayi yang lebih tua akan melokalisasi tubuhnya dengan cara menarik diri dari tempat yang sakit, menangis dengan keras, ekspresi wajah menunjukkan kemarahan (karaktersitik wajah sama dengan respon nyeri bayi muda namun mata terbuka), resistensi fisik dan mendorong stimulasi penyebab nyeri, setelah merasakan nyeri.

Bayi tidak dapat berkomunikasi melalui verbal secara menyeluruh, walaupun tingkah laku mereka menampilkan ekspresi wajah nyeri seperti: menangis, wajah meringis, mata menyipit, dagu bergetar. Bayi secara sempurna bergantung kepada tenaga medis untuk mengkaji nyeri dan menginterpretasikan nyeri mereka. Pengukuran tingkat nyeri pada bayi dan anak dibedakan berdasarkan usia anak dengan menggunakan skala yang telah teruji baik validitas maupun reliabilitasnya. Bayi belum dapat mengungkapkan rasa sakit dengan menggunakan kosa kata.Oleh karena itu perawat perlu mengkaji respon nyeri dari perilaku bayi ketika mengalami nyeri.

Salah satu intervensi yang dapat dikembangkan dalam menerapkan perawatan atraumatik saat pemberian imunisasi pada anak adalah terapi dekapan. Berdasarkan penelitian yang dilakukan oleh Lestari K.B, (2013), menyebutkan bahwa terdapat perbedaan rata-rata skor distress pada anak yang diberikan dekapan orang tua $(2,30)$ dan skor distress anak yang tidak mendapat dekapan orang tua $(3,25)$. Terapi dekapan juga sejalan dengan prinsip keperawatan anak lainnya yaitu memberdayakan keluarga dalam intervensi yang diberikan (family centered care) (Hedden et al., 2013).

Terapi dekapan merupakan kombinasi dari tindakan restrain dan pemilihan posisi yang nyaman saat dilakukan tindakan invasif juga dapat berpengaruh terhadap kenyamanan anak 
dan meminimalkan distres. Tujuan pemberian posisi yang nyaman adalah immobilisasi ekstremitas anak saat dilakukan prosedur, memberikan rasa aman dan senang bagi anak melalui kontak langsung dengan orang tua (The Children's Mercy Hospital, 2012). Pemberian posisi dekapan lebih menciptakan rasa kontrol, sehingga lebih sedikit orang yang diperlukan untuk menyelesaikan prosedur. Posisi dekapan dikembangkan untuk mempromosikan kenyamanan bagi anak, imobilisasi yang cukup, anak dapat diajak kerjasama dan kontrol diri anak dapat dipertahankan, sehingga anak menjadi tenang saat prosedur.

Berdasarkan latar belakang di atas, maka rumusan masalah penelitian ini adalah bagaimana efektifitas terapi dekapan terhadap penurunan intensitas nyeri pada bayi yang menjalani imunisasi?. Tujuan dalam penelitian ini adalah untuk menganalisis efektifitas terapi dekapan terhadap nyeri pada bayi yang dilakukan imunisasi di Puskesmas Lerep

\section{Metode penelitian}

Penelitian dilaksanakan pada bulan Oktober 2020 di Puskesmas Lerep Kabupaten Semarang, Jawa Tengah. Penelitian ini menggunakan pendekatan kuantitatif, desain penelitian yang digunakan dalam penelitian ini adalah Preeksperimental design dengan rancangan pretestpost test control group design.

Populasi dalam penelitian ini adalah bayi yang diberikan imunisasi di Puskesmas Lerep. Jumlah sampel dalam penelitian ini adalah 60 terdiri dari 30 kelompok kontrol dan 30 kelompok intervensi. Teknik sampel yang digunakan adalah dengan purposive sampling dengan kriteria inklusi bayi berusia 0-9 bulan dan bayi yang dilakukan imunisasi. Sedangkan kriteria esklusi bayi tidak diantar oleh ibu dan bayi demam.

Dalam penelitian ini ada 2 variabel yang diukur yaitu variabel Nyeri dan pemberian terapi dekapan ibu. Variabel nyeri diukur menggunakan instrument FLACC Pain Assessment Tools. Penilaian tersebut adalah ekspresi muka (0-2), gerakan kaki (0-2), aktivitas (0-2), menangis (0-2), kemampuan dihibur (0-2). Hasil skor perilakunya adalah : 0 : Tidak Nyeri, 1-3 : nyeri ringan/ ketidaknyamanan ringan, 4-6 : nyeri sedang dan 7-10 : nyeri hebat/ ketidaknyamanan berat.

Sedangkan variabel terapi dekapan ibu diukur dengan melakukan observasi saat pemberian imunisai. Pada kelompok intervensi diberikan perlakukan yaitu terapi dekapan ibu dan pada kelompok kontrol bayi diletakkan di kasur bayi yang ditunggui oleh ibunya. Uji normalitas data menggunkan saphiro wilk dengan $p$ value pada kelompok intervensi dan kontrol $>0.05$ sehingga dikatakan data normal. Uji statistik yang digunakan adalah dengan $t$ test-independent.

\section{HASIL PENELITIAN}

\section{Analisis Univariat}

\section{Karakteristik Nyeri pada Bayi yang dilakukan Imunisasi}

Tabel 1

Karakteritik Nyeri pada Responden yang dilakukan Imunisasi

\begin{tabular}{|c|c|c|c|c|c|}
\hline Variabel & Kelompok & Fase & Mean & $\mathrm{SD}$ & Min - max \\
\hline \multirow{4}{*}{$\begin{array}{l}\text { Nyeri } \\
\text { pada } \\
\text { Bayi }\end{array}$} & \multirow[t]{2}{*}{ Kontrol } & Sebelum & 0,3 & 1,149 & $0-6$ \\
\hline & & Sesudah & 5,7 & 1,466 & $0-9$ \\
\hline & \multirow[t]{2}{*}{ Intervensi } & Sebelum & 0,13 & 0,571 & $0-3$ \\
\hline & & Sesudah & 2,13 & 0,86 & $0-3$ \\
\hline
\end{tabular}


Tabel 1. menunjukkan rata-rata nyeri pada bayi sebelum diberikan imunisasi pada kelompok kontrol yaitu 0,3 dengan skala nyeri ringan pada skala FLACC dan terjadi peningkatan setelah diberikan imunisasi sebesar 5,7 atau skala nyeri sedang pada skala FLACC. Sedangkan pada kelompok intervensi, rata-rata nyeri pada bayi sebelum dilakukan imunisasi adalah 0,13 atau skala nyeri ringan pada skala FLACC dan meningkat setelah dilakukan imunisasai sebesar 2,13 atau skala nyeri ringan pada skala FLACC.

\section{Analisis Bivariat}

\section{Perbedaan Nyeri Sebelum dan Sesudah dilakukan Imunisasi pada Kelompok Kontrol dan Intervensi}

Tabel 2

Perbedaan nyeri responden sebelum dan setelah imunisasi pada kelompok intervensi dan kontrol

\begin{tabular}{|c|c|c|c|c|c|c|}
\hline Variabel & Kelompok & Fase & Mean & SD & $\begin{array}{c}\text { Selisih rerata } \\
(95 \% \mathrm{CI})\end{array}$ & Nilai $p$ \\
\hline \multirow{4}{*}{$\begin{array}{l}\text { Nyeri } \\
\text { pada } \\
\text { Bayi }\end{array}$} & \multirow[t]{2}{*}{ Kontrol } & Sebelum & 0,3 & 1,149 & \multirow[t]{2}{*}{$-5,40$} & \multirow[t]{2}{*}{0,0001} \\
\hline & & Sesudah & 5,7 & 1,466 & & \\
\hline & \multirow[t]{2}{*}{ Intervensi } & Sebelum & 0,13 & 0,571 & \multirow[t]{2}{*}{$-2,00$} & \multirow[t]{2}{*}{0,0001} \\
\hline & & Sesudah & 2,13 & 0,86 & & \\
\hline
\end{tabular}

Tabel 2 menunjukkan rata - rata nyeri pada bayi sebelum imunisasi pada kelompok kontrol yaitu 0,3 (tidak nyeri) sedangkan setelah imunisasi yaitu 5,7 (nyeri sedang). Adapun perbedaan rata - rata nyeri pada kelompok kontrol yaitu sebesar -5,4 dengan nilai p 0,0001. Berdasarkan hasil analisis diketahui bahwa ada perbedaan nyeri pada sebelum dan setelah dilakukan imunisasi pada kelompok kontrol $(\mathrm{p}<0,05)$.

Tabel 2 juga menunjukkan rata - rata nyeri pada bayi sebelum imunisasi pada kelompok intervensi yaitu 0,13 (tidak nyeri), sedangkan setelah imunisasi yaitu 2,13 (nyeri ringan). Adapun perbedaan rata - rata nyeri pada kelompok intervensi yaitu sebesar -2,0 dengan nilai p 0,0001. Berdasarkan hasil analisis diketahui bahwa ada perbedaan nyeri pada sebelum dan setelah dilakukan imunisasi pada kelompok intervensi $(\mathrm{p}<0,05)$.

a. Perbedaan Nyeri setelah imunisasi pada kelompok kontrol dan intervensi

\section{Tabel 3}

Perbedaan nyeri Setelah Imunisasi pada kelompok kontrol dan intervensi

\begin{tabular}{llllcc}
\hline \multicolumn{1}{c}{ Variabel } & Kelompok & Mean & SD & $\begin{array}{c}\text { Selisih rerata } \\
(95 \% \mathrm{CI})\end{array}$ & Nilai p \\
\hline $\begin{array}{l}\text { Nyeri } \\
\text { setelah } \\
\text { imunisasi }\end{array}$ & Kontrol & 5,7 & 1,466 & 3,567 & 0,0001 \\
\cline { 2 - 4 } & Intervensi & 2,13 & 0,86 & & \\
\hline
\end{tabular}

Tabel 3 menunjukkan rata - rata nyeri pada bayi setelah diberikan imunisasi pada kelompok kontrol yaitu 5,7 (nyeri sedang), sedangkan setelah imunisasi pada kelompok intervensi rata - rata nyeri yaitu 2,13 (nyeri ringan). Adapun perbedaan rata - rata nyeri setelah dilakukan imunisasi pada kelompok kontrol dan intervensi yaitu sebesar 3,567 dengan nilai p 0,0001. Berdasarkan hasil analisis diketahui bahwa ada perbedaan nyeri pada kelompok intervensi dan kontrol setelah dilakukan imunisasi $(p<0,05)$. 
Berdasarkan nilai skala FLACC dapat kita lihat bahwa skala nyeri pada kelompok intervensi lebih rendah dibandingkan dengan skala nyeri pada kelompok kontrol, sehingga dapat disimpulkan bahwa terapi dekapan dapat menurunkan skala nyeri pada kelompok intervensi.

b. Perbedaan selisih rata-rata nyeri pada kelompok kontrol dan intervensi

\begin{tabular}{clllcl} 
& \multicolumn{3}{c}{ Tabel 4 Perbedaan selisih rata - rata nyeri } \\
Pada kelompok kontrol dan intervensi & \\
\hline \multicolumn{1}{c}{ Variabel } & Kelompok & Mean & SD & $\begin{array}{c}\text { Selisih rerata } \\
(95 \% \mathrm{CI})\end{array}$ & Nilai $\mathrm{p}$ \\
\hline $\begin{array}{l}\text { Selisih nyeri } \\
\text { pada Bayi }\end{array}$ & Kontrol & 5,40 & 1,610 & 3,400 & 0,0001 \\
\cline { 2 - 5 } & Intervensi & 2,0 & 0,947 & & \\
\hline
\end{tabular}

Tabel 4 menunjukkan selisih rata - rata nyeri pada kelompok kontrol yaitu 5,4 (SD 1,610), sedangkan pada kelompok intervensi rata - rata nyeri yaitu 2,0 (SD 0,947). Adapun perbedaan selisih rata - rata nyeri pada kelompok kontrol dan intervensi yaitu sebesar 1,833 dengan nilai p 0,0001. Berdasarkan hasil analisis diketahui bahwa ada perbedaan selisih rata-rata nyeri pada kelompok intervensi dan kontrol $(\mathrm{p}<0,05)$. Dari hasil tersebut dapat disimpulkan intervensi terapi dekapan yang dilakukan pada kelompok intervensi efektif untuk menurunkan skala nyeri bayi pada tindakan imunisasi.

\section{PEMBAHASAN}

Nyeri merupakan stimulus yang dirasakan oleh sensoris dan bersifat subjektif, nyeri yang dialami seorang anak akan mempengaruhi dan melibatkan perkembangan, fisiologis, psikologis dan faktor-faktor situasional pada anak tersebut (American Academy of Pediatrics (AAP) \& American Pain Society (APS), 2013). Nyeri merupakan respon proteksi dari potensi atau sedang terjadinya kerusakan jaringan tubuh (Wong et al, 2009). Nyeri pada anak biasanya direkam sebagai pengalaman traumatik yang tidak menyenangkan.

Berdasarkan hasil penelitian pada tabel 1 didapatkan hasil bahwa pada kelompok kontrol rata-rata mengalami peningkatan nyeri yaitu yaitu 0,3 dengan skala nyeri ringan pada skala FLACC dan terjadi peningkatan setelah diberikan imunisasi sebesar 5,7 atau skala nyeri sedang ssedangkan pada kelompok intervensi rata-rata nyeri pada bayi sebelum dilakukan imunisasi adalah 0,13 atau skala nyeri ringan pada skala FLACC dan meningkat setelah dilakukan imunisasai sebesar 2,13 atau skala nyeri ringan pada skala FLACC.

Sejumlah cara penilaian nyeri telah dikembangkan untuk mengukur nyeri pada anak. Pengukuran nyeri dibagi menjadi 2 kategori, yaitu: pengukuran objektif (objective measures) digunakan untuk mengobservasi skor parameter perilaku (behavioral measures), atau fisiologis (physiologic measures), dan pengukuran subjektif (subjective measures) yaitu laporan diri (self report measures) yang digunakan agar anak dapat mengukur nyerinya (Hockenberry \& Wilson, 2009; Potts \& Mandleco, 2012).

Pengkajian perilaku sangat berguna untuk mengukur nyeri pada bayi dan anak preverbal yaitu anak yang belum memiliki kemampuan untuk mengkomunikasikan nyeri yang dirasakan, atau pada anak dengan gangguan mental yang memiliki kemampuan yang terbatas dalam menyampaikan kalimat yang memiliki arti. Pengukuran ini bergantung pada observer dalam mengamati dan merekam perilaku anak misalnya vokalisasi (suara), ekspresi wajah, dan gerak tubuh yang menunjukkan ketidaknyamanan. Pengukuran nyeri melalui pengamatan perilaku seringkali reliabel dalam mengukur nyeri akut, nyeri dari prosedur yang 
tajam seperti injeksi dan pungsi lumbar, namun kurang reliabel saat mengukur nyeri yang berkepanjangan (Hockenberry \& Wilson, 2009).

Tindakan invasif atau intervensi yang menimbulkan nyeri merupakan salah satu hal yang ingin diminimalisasi atau dihilangkan dalam prinsip atraumatic care. Pengalaman nyeri yang menimbulkan trauma dan distres sedapat mungkin tidak terjadi dalam setiap tindakan invasif. Teknik pengalihan nyeri yang tepat dapat secara signifikan mengurangi distres yang akan dialami (Wong et al., 2009).

Berdasarkan tabel 3 didapatkan bahwa rata - rata nyeri pada bayi sebelum imunisasi pada kelompok kontrol yaitu 0,3 (tidak nyeri) sedangkan setelah imunisasi yaitu 5,7 (nyeri sedang) ada peningkatan nyeri karena pada kelompok kontrol bayi hanya diletakkan di tempat tidur. Sedangkan pada kelompok kelompok intervensi yaitu 0,13 (tidak nyeri), sedangkan setelah imunisasi yaitu 2,13 (nyeri ringan) peningkatan nyeri tidak signifikan karena bayi diberikan perlakukan dengan terapi dekapan.

Terapi dekapan atau disebut juga dengan terapi memegang (comfort holding), clinical holding atau imobilisasi merupakan tindakan untuk membatasi gerakan anak (Brenner, Parahoo, \& Taggarat, 2007). Terapi dekapan merupakan salah satu bentuk restrain yang digunakan untuk membantu pelaksanaan prosedur pada anak yang kurang kooperatif, untuk melarang campur tangan anak dalam prosedur dan peralatan (Bray L, Snodin J, Carter B. 2015). Strategi non farmakologis untuk manajemen nyeri, seperti bedung yang dikombinasikan dengan posisi, holding the infant (menahan bayi dalam posisi tertekuk dengan lengan dekat dengan tubuh) dengan atau tanpa bantuan orang tua dan isapan non nutritif, telah menunjukkan efektivitas variabel dalam mengurangi nyeri (Aap Committee On Fetus And Newborn And Section On Anesthesiology And Pain Medicine, 2016).

Berdasarkan hasil penelitian pada tabel 4 dan 5 Ada perbedaan rata - rata nyeri setelah dilakukan imunisasi pada kelompok kontrol dan intervensi yaitu sebesar 3,567 dengan nilai p 0,0001, sehingga didapatkan bahwa dengan anak diberikan terapi dekapan dapat menurunkan rata-rat nyeri pada bayi yang diberikan imunisasi. Terapi dekapan merupakan penggunaan posisi yang nyaman, aman, dan temporer yang memberikan kontak fisik yang erat dengan orang tua atau pengasuh (Hockenberry \& Wilson, 2009). Terdapat teori yang menyebutkan bahwa kehadiran orang tua dan orang terdekat sangat penting bagi anak-anak yang sedang mengalami nyeri (Potter and Perry. 2020). Penelitian ini sejalan dengan Penelitian yang dilakukan oleh Wahyuni, F., \& Suryani, U. (2020) bahwa terapi mendekap lebih efektif dalam menurunkan skala nyeri pada bayi saat dilakukan imunisasi campak.

Terapi dekapan dilakukan dengan memposisikan badan anak menghadap ke ibu, dimana dada anak bertemu dengan dada ibu. Terapi dekapan berbeda dengan pembatasan aktivitas fisik lainnya. Perbedaannya terletak pada tingkat kekuatan dan keterlibatan anak. Menahan bayi saat imunisasi dalam posisi menghadap ibu lebih efektif dalam meredakan nyeri vaksinasi daripada menahan dalam posisi tegak. Dengan demikian, sebaiknya memegang posisi mendekap ibu dapat membantu mengurangi nyeri vaksinasi pada bayi (Yin et al, 2017). Terapi ini juga dapat meningkatkan rasa nyaman dan meminimalkan dampak perpisahan dengan orang tua sehingga dapat mengurangi distres yang timbul akibat hospitalisasi (Giese, 2010).

Terapi dekapan tidak dapat terlepas dari pemberian posisi yang nyaman bagi anak. Pemberian posisi ini merupakan teknik yang teat dalam membantu meminimalkan dampak distres pada anak saat dilakukan prosedur invasive Ball, J. W., Bindler, R. C., \& Cowen, K. J( 2012). Pemberian posisi ini dapat dilakukan dalam berbagai macam tindakan invasif diantaranya pemasangan infus, pengambilan sampel darah, pemasangan NGT, imunisasi dan pemberian injeksi. Tujuan pemberian posisi yang nyaman menurut The Children Mercy Hospital (2010) adalah untuk imobilisasi ekstremitas anak saat dilakukan prosedur, memberikan rasa aman dan senang bagi anak, memberikan kenyamanan melalui kontak 
langsung dengan orang tua. Orang tua berpartisiasi memberikan bantuan posisi bukan dalam bentuk menahan secara negatif. Dipegang oleh pengasuh direkomendasikan oleh WHO untuk bayi dan anak kecil yang menerima suntikan vaksin (WHO, 2015).

\section{Simpulan}

Berdaskan hasil penelitian dapat disimpulkan

1. Adanya peningkatan intensitas nyeri sebelum dan sesudah dilakukan perlakuan yang signifikan pada kelompok kontrol dari tidak nyeri ke skala nyeri sedang. Peningkatan nyeri pada kelompok intervensi sebelum dan sesudah dilakukan terapi dekapan ibu dari tidak nyeri ke nyeri ringan

2. Berdasarkan hasil analisis diketahui bahwa ada perbedaan nyeri pada kelompok intervensi dan kontrol setelah dilakukan imunisasi ( $p$ value : $0,0001<0,005$ )

3. Berdasarkan selisih rata-rata nyeri pada kelompok kontrol dan intervensi terdapat penurunan skala nyeri pada kelompok intevensi. ( $p$ value $0,0001<0,005$ )

\section{Saran}

1. Puskesmas

Diharapkan Tenaga Kesehatan di Puskesmas menerapkan tindakan atraumatic care pada bayi yang akan dilakukan imunisasi dengan cara mengikutsertakan ibu dalam kegiatan imunisasi yaitu dengan dekapan ibu

2. Ibu

Ibu diharapkan selalu mendampingi bayi ketika dilakukan imunisasi untuk meningkatkan bonding dan memberikan kenyamanan bayi ketika diimunisasi

\section{Daftar Pustaka}

Aap Committee On Fetus And Newborn And Section On Anesthesiology And Pain Medicine. Prevention and Management of Procedural Pain in the Neonate: An Update. Pediatrics. 2016. ;137(2):e20154271. Daimbil dari https://pediatrics.aappublications.org/content/137/2/e20154271 diakses tanggal 25 november 2020.

American Family Children's Hospital. (). Comfort positioning for procedures for pediatric patients. dari http://www.uwhealth.org/ Diakses pada tanggal 28 september 2020

Ball, J. W., Bindler, R. C., \& Cowen, K. J. 2012. Principles of pediatric nursing: caring for children (5th Edition). New Jersey: Pearson Education, Inc.

Birmaher, B., Khetarpal, S., Cully, M., Brent, D., \& McKenzie, S. 2012. Screen for child anxiety related emotional disorders (scared). Retrieved from www.wpic.pitt.edu/research

Bray L, Snodin J, Carter B. 2015. Holding and restraining children for clinical procedures within an acute care setting: an ethical consideration of the evidence. Nurs Inq. 2015 Jun;22(2):157-67. doi: 10.1111/nin.12074.. Diakses dari https://pubmed.ncbi.nlm.nih.gov/25053126/ pada tanggal 20 november 2020

Geise, H. 2010. Positioning for comfort, St. Joseph Children Hospital. Retrieved from: http://ministryhealth.org,

Guyton, A.C., \& Hall, J.E. 2007. Buku ajar fisiologi kedokteran, Edisi 11. Jakarta: EGC.

Heden, L., Poder, U., Von Essen, L., \& Ljungman, G. (2013). Parents' perceptions of their child's symptom burden during and after cancer treatment. Journal of Pain and Symptom Management, 46(3), 366-375. http://doi.org/10.1016/j.jpainsymman.2012.09.012 
Hockenberry M \& Wilson D. 2009. Wong's nursing care of infants and children,(8 ${ }^{\text {th }}$ ed.). St. Louis: Mosby, Inc.: Elsevier

Lestari, K.B. 2013. Dampak dekapan keluarga dan pemberian posisi duduk terhadap distress anak saat dilakukan pemasangan infus. Tesis UI. Tidak dipublikasikan

Mc Murtry, C. M., Noel, M., Chambers, C. T., \& McGrath, P. J. 2011. Children's fear during procedural pain: Preliminary investigation of the children's fear scale. Health Psychology, 30(6), 780-788 http://dx.doi.org/10.1037/a0024817

Ponidjan, T. S. (2013). Efektifitas posisi duduk dalam dekapan keluarga terhadap stres anak prasekolah yang dilakukan prosedur pengambilan spesimen darah infus. Tesis Fakultas Ilmu Keperawatan UI. Tidak Dipublikasikan.

Potter and Perry. 2020. Dasar-dasar Keperawatan. Edisi 9. Elsevier : Mosby Elsevier, Inc.

Potts, N.L., \& Mandleco, B.L. 2012. Pediatric nursing caring for children and their families. $\left(3^{\text {rd }}\right.$ ed.). New York: Delmar Cengage Learning.

Purwanto \& Zulaekah, 2007. Pengaruh pelatihan relaksasi religious untuk menguragi gangguan insomnia, (online)

Sari, E. (2014). Perbandingan Efektifitas Antara Metode Bounding (Dekapan) Dan Stimulus Kutaneus Dalam Mengurangi Rasa Nyeri Suntikan Intramuskuler Pada Bayi. Jurnal Keperawatan. Diambil dari http://jurnal.stikeswilliambooth.ac.id/index.php/d3kep/article/view/16 . Diakses pada tanggal 26 November 2020

Sarimin S., Moningka L., Jansen A. (2015). Gambaran respon perilaku nyeri bayi pada pemberian suntikan imunisasi dasar di Puskesmas Bahu Kecamatan Malalaya Kota Manado. Juiperdo, 4(1): 38-46.

Wahyuni, F., \& Suryani, U. 2020. Efektifitas Terapi Mendekap Dan Terapi Musik Dalam Menurunkan Skala Nyeri Pada Bayi Saat Dilakukan Imunisasi Campak. Jurnal Keperawatan Terpadu (Integrated Nursing Journal), 2(2), 103-118.. diakses dari http://jkt.poltekkes-mataram.ac.id/index.php/home/article/view/58 . Pada tanggal 26 November 2020

WHO, "Reducing pain at the time of vaccination: WHO posi-tion paper-September 2015,"Weekly Epidemiological Record,vol.90,no.39,pp.505-510,2015

Wong, D.L., Hockenberry, E.M., Wilson, D., Wilkelstein, M.L., \& Kline, N.E. 2009. Nursing care of infants and chidren. Ten edition. Missouri: Mosby, Inc.

Yin HC, Cheng SW, Yang CY, Chiu YW, Weng YH. Comparative Survey of Holding Positions for Reducing Vaccination Pain in Young Infants. Pain Res Manag. 2017;2017:3273171. doi: 10.1155/2017/3273171. Epub 2017 Jan 26. Diakses dari : https://pubmed.ncbi.nlm.nih.gov/28246489/ pada tanggal 22 November 2020 